\title{
CHANGING MORTALITY FROM 1841 TO 1947 MEASURED BY THE LIFE TABLE
}

\author{
BY \\ WALLIS TAYLOR \\ Central Statistical Office, City of Birmingham
}

Until the mid-1930s there were wide discrepancies in the expectation of life in four major English-speaking communities, viz. England and Wales, U.S.A., Australia, and New Zealand. The initial aim of this communication was to draw attention to a spectacular, unequal, and concurrent rise, the outcome of which is that the latest figures differ little inter se. A closer examination of contributory changes in different age groups prompted the question: in what age groups has the conservation of life during the past century been pre-eminently responsible for the continuous rise of the expectation of life in England and Wales during the same period? The answer will permit us to see more clearly what age groups can materially participate in further improvement henceforth.

Though we may credit an Englishman, Halley (1693), with the making of the first life table, the data he employed refer to a German city and are grossly defective as regards the age structure of the population. In 1783 Richard Price published a table referable to Northampton, the first of its kind to use British data. Unfortunately the errors in this table enabled the insurance companies to net a small fortune from life insurance, and H.M. government lost $£ 2$ million by it.

For British life-table statistics in which we can place much confidence we cannot go back earlier than Farr (1843), though a Table based on deaths for 1774-87 in the city of Carlisle was published by Milne (1815). During the 19th century the procedure changed little, though greater reliability resulted from better registration. There is no need to add what Dublin and others (1949) or Kuczynski (1935) have lately written concerning minor refinements in the technique. The symbols employed below are those now in general use, viz.:

If $\Delta$ be the age-group interval adopted (here 1 year for the first 5 years, and 5 years thereafter),

(1) $P_{x}$ is the proportion per thousand of persons who reach age $x+\Delta$, having themselves attained age $x$ years;

(2) $l_{x}$ is the number of survivors at age $x$ out of 1,000 at birth;

(3) $\mathrm{L}_{\Delta}$ is the mean number of years of survival of the same cohort during the age-group interval $(\Delta)$;

(4) $T_{x}$ is the cumulative number of years of survival by that cohort after attaining the age $x$;

(5) $\dot{e}_{x}$ is the mean number of remaining years of life at current mortality rates for persons at age $x$, so that $\dot{e}_{0}$ is the mean number of years of life at birth. 
The use of the word proportion in this context in preference to probability is intentional, as is the avoidance of the customary definition of $\dot{e}_{x}$ as the expectation of life at $x$ years. It is the writer's standpoint that $\dot{e}_{x}$ is essentially a summarizing index as are the other entries of the life table, which is collectively a battery of summarizing indices, each with a special significance but all alike referable to a unique historical situation - in contradistinction to a sample in the normal use of the term. Failure to make this distinction clear is perhaps partly responsible for the remarkable neglect of the life-table technique in favour of other and inferior methods of mortality standardization with respect to sex and age in official publications.

In theory, it would be possible to construct a Life Table based on the continuous history of a cohort up to the time of death of the last survivor, but one could not then use the life-table technique as a summary of the contemporary scene. The actual procedure records what the mortality experience of the cohort would be if mortality in each year of life were as at the date to which the table refers. Actually, we have good reason to expect that mortality will decrease during the remaining years of life of people now living. Accordingly the estimated number of years of survival from the life table is not in any meaningful sense the expectation of life at their birth. If he subsequently conforms to common usage by using this expression for $\dot{e}_{x}$, the present writer does not subscribe to the definition of the Government Actuary, writing on the 1930-1932 Life Tables:

" the total future life-time which, on an average, will be passed through by each of a group of persons aged exactly $x$ ".

This is crystal-gazing. If mortality rates fall heavily in the future, no amount of averaging will justify this statement.

Although the earlier Life Tables on record refer to cities (a practice followed by Farr (1875) in his selected tables for Healthy Districts), the contemporary ones are normally* available only for national units, though the technique calls for no data other than that required for any reliable method of standardization, in particular the age and sex structure of the population. In view of the wealth of neglected and diverse information summarized in the life-table battery, it is regrettable that the Registrar-General's Statistical Review does not make available an age and sex breakdown of the population of England and Wales for cities and other units of local government. $\dagger$

The life-table technique has certain limitations from the viewpoint of social medicine in that it is not pre-eminently suitable for the study of occupational

\footnotetext{
* The 1931 tables from the office of the Registrar-General do, however, include one for Greater London.

$\dagger$ This study developed from a comparison of life tables for England and Wales and for Birmingham, computed for the analysis of migration and the age structure of future populations. Such research is severely handicapped by the lack of local sex and age estimates, since there is a gap between 1931 and 1947. It is interesting to note, therefore, that the population of the City of Birmingham is now 1,107,200 (1949) and the population of New Zealand (non-Maori) 1,802,000 (1947). The published statistics in no way reflect the comparability.
} 
differentials; but Dublin and others (1949) showed that its uses are more diverse than its customary identification with the assessment of insurance premiums by estimating man-years lost by premature decease due to particular diseases. Since we are about to compare life-table statistics of different natural communities, it is appropriate to comment upon certain difficulties which beset such comparison. It is all too customary to identify the use of the Life Table with the information embodied in the single summarizing index $\dot{e}_{0}$. It may, however, happen in some statistically backward countries that portions of the Life Table vary in accuracy. Some portions may even be omitted, as in Canada in 1931, where the errors in registration for the first 5 years of life were known to be large and the Life Table was started at age five.

The problem arises, therefore, of choosing the relevant part for comparison. Certainly for general comparison $\dot{e}_{0}$ is the best value, but if birth registration is known to be inefficient, it may be far better to compare $\dot{e}_{5}$ or a later value. If infant welfare is our main preoccupation, $\dot{e}_{0}$ can be compared with $\dot{e}_{1}$. If $\dot{e}_{1}$ is much larger than $\dot{e}_{0}$ then high infant mortality is taking place; if $\dot{e}_{1}$ is less by nearly one year, then infant mortality is very low. If our concern is to compare the potential reproductive powers of each community, it may be most interesting to set side by side survivors at the end of the reproductive period from cohorts of equal size at the beginning of it.

Before we turn to consider the changing incidence of mortality between 19301932 and 1946-1948, it is perhaps politic to point out that by the nature of its construction this index does not show the loss of life directly due to the intervening war. This is perhaps a further reason for avoiding the term "expectation of life". The years of life lost by causes directly attributable to the war can, of course, be ascertained from a Life Table in the same way as the loss of years due to accident or a specific disease. Farr (1875) attempted this for zymotic diseases, phthisis, and cancer, and he quoted the work of Duvillard (1806), who estimated the loss of life due to smallpox in Paris in 1806 as 3.5 years. No more recent publication by the Registrar-General using this type of calculation is known to the author.

It is in the international comparison of mortality that the value of the Life Table is so clearly demonstrated. Its adoption would dispense with any need for international agreement on a "standard" population, and would not be open to the objections which the choice of any such standard incurs when the communities concerned differ widely in population structure.

\section{The Contemporary Life Table of Four English-Speaking Communities}

No Official British Life Table has appeared since 1931. Appendix A cites the writer's procedure for the construction of an abridged table for England and Wales referable to the years 1946-48 (Table I, opposite). The outstanding changes between these two dates are described below.

First and foremost is a very great increase in $\dot{e}_{0}$ for both sexes. Over these 
TABLE I

Life TABle 1946-1948, ENGland AND Wales

\begin{tabular}{|c|c|c|c|c|c|}
\hline Exact Age & $P_{x}$ & $l_{x}$ & $L_{\Delta}$ & $T_{x}$ & $\dot{e}_{x}$ \\
\hline $\begin{array}{c}\text { Males } \\
\end{array}$ & $955 \cdot 98$ & $1,000 \cdot 00$ & $964 \cdot 51$ & $65,317 \cdot 99$ & $65 \cdot 32$ \\
\hline $\begin{array}{l}1 \\
2 \\
3 \\
4\end{array}$ & $\begin{array}{l}996 \cdot 63 \\
997 \cdot 98 \\
998 \cdot 51 \\
998 \cdot 72\end{array}$ & $\begin{array}{l}955 \cdot 98 \\
952 \cdot 76 \\
950 \cdot 83 \\
949 \cdot 42\end{array}$ & $\begin{array}{l}954 \cdot 37 \\
951 \cdot 79 \\
950 \cdot 12 \\
948 \cdot 81\end{array}$ & $\begin{array}{l}64,353 \cdot 48 \\
63,399 \cdot 12 \\
62,447 \cdot 33 \\
61,497 \cdot 20\end{array}$ & $\begin{array}{l}67 \cdot 32 \\
66 \cdot 54 \\
65 \cdot 68 \\
64 \cdot 77\end{array}$ \\
\hline $\begin{array}{r}5 \\
10 \\
15 \\
20 \\
25 \\
30 \\
35 \\
40 \\
45 \\
50 \\
55 \\
60 \\
65 \\
70 \\
75 \\
80\end{array}$ & $\begin{array}{l}995 \cdot 23 \\
996 \cdot 25 \\
992 \cdot 37 \\
990 \cdot 97 \\
990 \cdot 89 \\
989 \cdot 29 \\
986 \cdot 66 \\
980 \cdot 19 \\
967 \cdot 12 \\
947 \cdot 24 \\
916 \cdot 72 \\
870 \cdot 20 \\
815 \cdot 30 \\
729 \cdot 12 \\
605 \cdot 98 \\
447 \cdot 01\end{array}$ & $\begin{array}{l}948 \cdot 20 \\
943 \cdot 67 \\
940 \cdot 13 \\
932 \cdot 96 \\
924 \cdot 54 \\
916 \cdot 11 \\
906 \cdot 31 \\
894 \cdot 21 \\
876 \cdot 50 \\
847 \cdot 69 \\
802 \cdot 96 \\
736 \cdot 09 \\
640 \cdot 55 \\
522 \cdot 24 \\
380 \cdot 77 \\
230 \cdot 74\end{array}$ & $\begin{array}{r}4,729 \cdot 68 \\
4,709 \cdot 52 \\
4,682 \cdot 74 \\
4,643 \cdot 75 \\
4,601 \cdot 62 \\
4,556 \cdot 06 \\
4,501 \cdot 30 \\
4,426 \cdot 78 \\
4,310 \cdot 47 \\
4,126 \cdot 62 \\
3,847 \cdot 63 \\
3,44 \cdot 61 \\
2,906 \cdot 96 \\
2,257 \cdot 53 \\
1,528 \cdot 78 \\
834 \cdot 71\end{array}$ & $\begin{array}{r}60,548 \cdot 40 \\
55,818 \cdot 71 \\
51,109 \cdot 19 \\
46,426 \cdot 45 \\
41,782 \cdot 70 \\
37,181 \cdot 08 \\
32,625 \cdot 03 \\
28,123 \cdot 72 \\
23,969 \cdot 94 \\
19,386 \cdot 47 \\
15,259 \cdot 86 \\
11,412 \cdot 22 \\
7,970 \cdot 61 \\
5,063 \cdot 66 \\
2,806 \cdot 12 \\
1,277 \cdot 34\end{array}$ & $\begin{array}{r}63 \cdot 86 \\
59 \cdot 15 \\
54 \cdot 36 \\
49 \cdot 76 \\
45 \cdot 19 \\
40 \cdot 59 \\
36 \cdot 00 \\
31 \cdot 45 \\
27 \cdot 04 \\
22 \cdot 87 \\
19 \cdot 00 \\
15 \cdot 50 \\
12 \cdot 44 \\
9 \cdot 70 \\
7 \cdot 37 \\
5 \cdot 54\end{array}$ \\
\hline $\begin{array}{r}85 \\
90 \\
95 \\
100\end{array}$ & $\begin{array}{c}297 \cdot 02 \\
199 \cdot 95 \\
31 \cdot 65 \\
-\end{array}$ & $\begin{array}{r}103 \cdot 14 \\
30 \cdot 64 \\
6 \cdot 13 \\
0 \cdot 19\end{array}$ & $\begin{array}{r}334 \cdot 45 \\
91 \cdot 90 \\
15 \cdot 80 \\
0.48\end{array}$ & $\begin{array}{r}442 \cdot 63 \\
108 \cdot 19 \\
16 \cdot 28 \\
0 \cdot 49\end{array}$ & $\begin{array}{l}4 \cdot 29 \\
3 \cdot 53 \\
2 \cdot 66 \\
2 \cdot 50\end{array}$ \\
\hline $\begin{array}{r}\text { Females } \\
0\end{array}$ & $965 \cdot 87$ & $1,000 \cdot 00$ & $972 \cdot 76$ & $70,046 \cdot 04$ & $70 \cdot 05$ \\
\hline $\begin{array}{l}1 \\
2 \\
3 \\
4\end{array}$ & $\begin{array}{l}997 \cdot 03 \\
998 \cdot 29 \\
998 \cdot 80 \\
999 \cdot 04\end{array}$ & $\begin{array}{l}965 \cdot 87 \\
963 \cdot 00 \\
961 \cdot 36 \\
960 \cdot 21\end{array}$ & $\begin{array}{l}964 \cdot 44 \\
962 \cdot 18 \\
960 \cdot 78 \\
959 \cdot 74\end{array}$ & $\begin{array}{l}69,073 \cdot 28 \\
68,108 \cdot 85 \\
67,146 \cdot 67 \\
66,185 \cdot 89\end{array}$ & $\begin{array}{l}71 \cdot 51 \\
70 \cdot 73 \\
69 \cdot 85 \\
68 \cdot 93\end{array}$ \\
\hline $\begin{array}{r}5 \\
10 \\
15 \\
20 \\
25 \\
30 \\
35 \\
40 \\
45 \\
50 \\
55 \\
60 \\
65 \\
70 \\
75 \\
80\end{array}$ & $\begin{array}{l}996 \cdot 49 \\
996 \cdot 98 \\
994 \cdot 14 \\
991 \cdot 27 \\
990 \cdot 92 \\
990 \cdot 09 \\
988 \cdot 62 \\
984 \cdot 93 \\
977 \cdot 50 \\
966 \cdot 78 \\
951 \cdot 33 \\
923 \cdot 48 \\
880 \cdot 29 \\
801.49 \\
688 \cdot 10 \\
540 \cdot 89\end{array}$ & $\begin{array}{l}959 \cdot 28 \\
955 \cdot 91 \\
953 \cdot 02 \\
947 \cdot 43 \\
939 \cdot 17 \\
930 \cdot 64 \\
921 \cdot 41 \\
910 \cdot 93 \\
897 \cdot 20 \\
877 \cdot 01 \\
847 \cdot 88 \\
806 \cdot 61 \\
744 \cdot 89 \\
655 \cdot 72 \\
525 \cdot 55 \\
361 \cdot 63\end{array}$ & $\begin{array}{l}4,787 \cdot 98 \\
4,772 \cdot 33 \\
4,751 \cdot 13 \\
4,716 \cdot 50 \\
4,674 \cdot 51 \\
4,630 \cdot 12 \\
4,580 \cdot 86 \\
4,520 \cdot 33 \\
4,435 \cdot 53 \\
4,312 \cdot 23 \\
4,136 \cdot 22 \\
3,878 \cdot 74 \\
3,501 \cdot 52 \\
2,953 \cdot 18 \\
2,217 \cdot 95 \\
1,393 \cdot 07\end{array}$ & $\begin{array}{r}65,226 \cdot 15 \\
60,438 \cdot 16 \\
55,665 \cdot 84 \\
50,914 \cdot 70 \\
46,198 \cdot 21 \\
41,523 \cdot 70 \\
36,893 \cdot 58 \\
32,312 \cdot 71 \\
27,792 \cdot 39 \\
23,356 \cdot 85 \\
19,044 \cdot 63 \\
14,908 \cdot 41 \\
11,029 \cdot 67 \\
7,528 \cdot 14 \\
4,574 \cdot 97 \\
2,357 \cdot 02\end{array}$ & $\begin{array}{r}68 \cdot 00 \\
63 \cdot 23 \\
58 \cdot 41 \\
53 \cdot 74 \\
49 \cdot 19 \\
44 \cdot 62 \\
40 \cdot 04 \\
35 \cdot 47 \\
30 \cdot 98 \\
26 \cdot 63 \\
22 \cdot 46 \\
18 \cdot 48 \\
14 \cdot 81 \\
11 \cdot 48 \\
8 \cdot 70 \\
6 \cdot 52\end{array}$ \\
\hline $\begin{array}{r}85 \\
90 \\
95 \\
100\end{array}$ & $\begin{array}{c}384.00 \\
245 \cdot 06 \\
80.00 \\
-\end{array}$ & $\begin{array}{r}195 \cdot 60 \\
75 \cdot 11 \\
18 \cdot 41 \\
1 \cdot 47\end{array}$ & $\begin{array}{r}676 \cdot 78 \\
233 \cdot 79 \\
49 \cdot 70 \\
3 \cdot 68\end{array}$ & $\begin{array}{r}963 \cdot 95 \\
287 \cdot 16 \\
53 \cdot 38 \\
3 \cdot 68\end{array}$ & $\begin{array}{l}4 \cdot 93 \\
3 \cdot 82 \\
2 \cdot 90 \\
2 \cdot 50\end{array}$ \\
\hline
\end{tabular}


16 years $\dot{e}_{0}$ for males increased by 6.62 from 58.70 to $65 \cdot 32$ years, and for females by $7 \cdot 17$ from $62 \cdot 88$ to 70.05 years. In view of the economic and international upheavals of this period, this is a remarkable achievement. It prompts us, therefore, to consider the international scene to see whether or not it is an isolated phenomenon. From the United Nations Demographic Year Book (1948) we pick out three other countries which approach ethnic similarity, the U.S.A. (white), Australia (non-Aborigine), and New Zealand (non-Maori). To bring this picture up to date we have used Life Tables for 1947, computed by the Metropolitan Life Insurance Company, New York.*

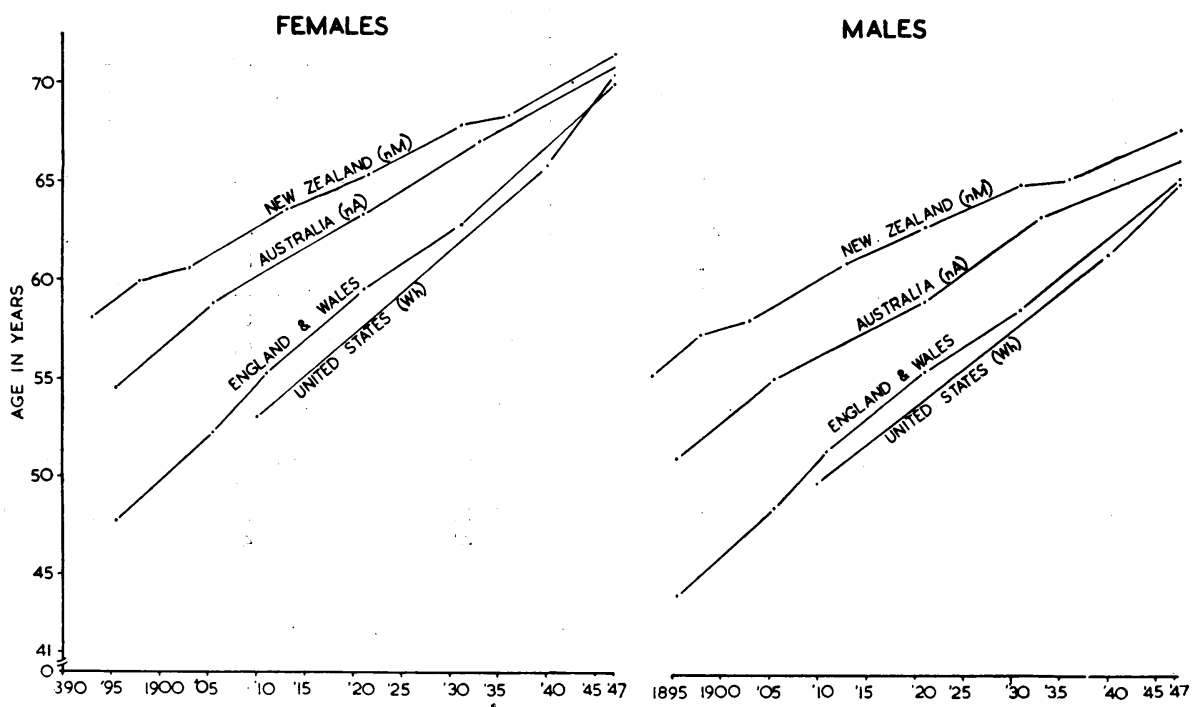

FIG. 1.-Historical comparison of $\dot{e}_{o}$ in English-speaking communities (white population only).

Fig. 1 shows that all four countries have reached a similar standard measured by $\dot{e}_{0}$, although their progression to that level is dissimilar. In fact, perhaps the most surprising change is the closure of the gap between these four countries. In about 1910 the range for males was 10 years, and by 1947 it was only $2 \cdot 16$ years; for females it decreased from about 9 to 1.6 years. New Zealand (nM) and Australia (nA) are still in the lead, but the U.S.A. (Wh) and England and Wales (following very similar paths) have now bridged most of the gulf which previously existed between them and the countries of the Southern hemisphere.

We can get the nature of this convergence into better focus if we compare the measures of mortality derived from the Life Table (Tables II and III). Both $l_{x}$ and $\dot{e}_{x}$ are given, since they are in a sense complementary. The former relates the experience of the cohort 0 to $x$, and the latter that of all ages greater than $x$. The three foreign tables are for the year 1947 alone. Computed on a similar basis,

\footnotetext{
* These figures are printed here by the courtesy of Dr. L. I. Dublin.
} 
CHANGING MORTALITY MEASURED BY LIFE TABLE

TABLE II

INTERNATIONAL Comparison OF Life-Table Survivors

\begin{tabular}{|c|c|c|c|c|}
\hline Exact Age & $\begin{array}{c}\text { England and Wales } \\
(1946-48)\end{array}$ & $\begin{array}{c}\text { Australia (nA) } \\
\text { (1947) }\end{array}$ & $\underset{(1947)}{\text { New }} \underset{\text { Zealand }(\mathrm{nM})}{ }$ & $\begin{array}{l}\text { U.S.A. (Wh) } \\
(1947)\end{array}$ \\
\hline $\begin{array}{r}\text { Males } \\
0 \\
1 \\
5 \\
10 \\
15 \\
20 \\
25 \\
30 \\
35 \\
40 \\
45 \\
50 \\
55 \\
60 \\
65 \\
70 \\
75 \\
80\end{array}$ & $\begin{array}{r}100,000 \\
95,598 \\
94,820 \\
94,367 \\
94,013 \\
93,296 \\
92,454 \\
91,611 \\
90,631 \\
89,421 \\
87,650 \\
84,769 \\
80,296 \\
73,609 \\
64,055 \\
52,224 \\
38,077 \\
23,074\end{array}$ & $\begin{array}{r}100,000 \\
96,827 \\
96,040 \\
95,549 \\
95,203 \\
94,556 \\
93,754 \\
92,966 \\
92,047 \\
90,848 \\
88,975 \\
86,071 \\
81,123 \\
74,447 \\
64,863 \\
52,598 \\
38,554 \\
23,439\end{array}$ & $\begin{array}{r}100,000 \\
97,275 \\
96,592 \\
96,202 \\
95,909 \\
95,394 \\
94,453 \\
93,677 \\
92,827 \\
91,798 \\
90,467 \\
87,870 \\
83,687 \\
77,501 \\
68,789 \\
56,694 \\
41,887 \\
25,856\end{array}$ & $\begin{array}{r}100,000 \\
96,550 \\
95,932 \\
95,558 \\
95,185 \\
94,509 \\
93,611 \\
92,694 \\
91,609 \\
90,061 \\
87,701 \\
84,158 \\
78,763 \\
71,477 \\
61,728 \\
49,512 \\
35,881 \\
22,347\end{array}$ \\
\hline $\begin{array}{r}\text { Females } \\
0 \\
1 \\
5 \\
10 \\
15 \\
20 \\
25 \\
30 \\
35 \\
40 \\
45 \\
50 \\
55 \\
60 \\
65 \\
70 \\
75 \\
80\end{array}$ & $\begin{array}{r}100,000 \\
96,587 \\
95,928 \\
95,591 \\
95,302 \\
94,743 \\
93,917 \\
93,064 \\
92,141 \\
91,093 \\
89,720 \\
87,701 \\
84,788 \\
80,661 \\
74,489 \\
65,572 \\
52,555 \\
36,163\end{array}$ & $\begin{array}{r}100,000 \\
97,488 \\
96,850 \\
96,572 \\
96,330 \\
95,989 \\
95,463 \\
94,737 \\
93,889 \\
92,747 \\
91,246 \\
89,150 \\
85,867 \\
81,565 \\
75,182 \\
65,911 \\
53,027 \\
36,646\end{array}$ & $\begin{array}{r}100,000 \\
97,728 \\
97,077 \\
96,923 \\
96,749 \\
96,343 \\
95,773 \\
95,030 \\
94,280 \\
93,325 \\
92,190 \\
90,033 \\
87,040 \\
82,639 \\
76,546 \\
67,566 \\
54,734 \\
37,991\end{array}$ & $\begin{array}{r}100,000 \\
97,350 \\
96,834 \\
96,573 \\
96,341 \\
95,965 \\
95,476 \\
94,884 \\
94,115 \\
93,042 \\
91,525 \\
89,301 \\
86,050 \\
81,464 \\
74,678 \\
64,589 \\
51,142 \\
35,293\end{array}$ \\
\hline
\end{tabular}

the English tables would give slightly lower values than appear here, since in 1947 England and Wales experienced higher mortality at almost all ages than in either 1946 or 1948 . It is clear that mortality experience in all age groups is now very similar in the four countries under discussion. Mortality of males is throughout heavier in England and Wales than in Australia (nA) or in New Zealand (nM) except that it appears to be slightly below that of New Zealand (nM) above age 80, but the difference here is trivial. Conversely, the summation of mortality gives a higher mortality figure to the U.S.A. (Wh), and of the cohort only 22,347 survive to age 80 against 23,074 in England and Wales. If we take the two tables together it is easy to see that the change occurs after age 45 , more surviving to this age in 
TABLE III

$1947 \dot{e}_{x}$

\begin{tabular}{|c|c|c|c|c|}
\hline Exact Age & $\underset{(1946-48)}{\text { England and Wales }}$ & $\begin{array}{c}\text { Australia (nA) } \\
(1947)\end{array}$ & $\underset{(1947)}{\text { New Zealand }}(\mathrm{nM})$ & $\begin{array}{l}\text { U.S.A. (Wh) } \\
\text { (1947) }\end{array}$ \\
\hline $\begin{array}{rr}\text { Males } & \\
& 0 \\
1 \\
5 \\
10 \\
15 \\
20 \\
25 \\
30 \\
35 \\
40 \\
45 \\
50 \\
55 \\
60 \\
65 \\
70 \\
75 \\
80\end{array}$ & $\begin{array}{r}65 \cdot 32 \\
67 \cdot 32 \\
63 \cdot 86 \\
59 \cdot 15 \\
54 \cdot 36 \\
49 \cdot 76 \\
45 \cdot 19 \\
40 \cdot 59 \\
36 \cdot 00 \\
31 \cdot 45 \\
27 \cdot 04 \\
22 \cdot 87 \\
19 \cdot 00 \\
15 \cdot 50 \\
12 \cdot 44 \\
9 \cdot 70 \\
7 \cdot 37 \\
5 \cdot 54\end{array}$ & $\begin{array}{r}66 \cdot 30 \\
67 \cdot 47 \\
64 \cdot 01 \\
59 \cdot 32 \\
54 \cdot 52 \\
49 \cdot 88 \\
45 \cdot 28 \\
40 \cdot 64 \\
36 \cdot 02 \\
31 \cdot 46 \\
27 \cdot 07 \\
22 \cdot 89 \\
19 \cdot 13 \\
15 \cdot 60 \\
12 \cdot 52 \\
9 \cdot 83 \\
7 \cdot 48 \\
5 \cdot 71\end{array}$ & $\begin{array}{r}67 \cdot 77 \\
68 \cdot 67 \\
65 \cdot 14 \\
60 \cdot 39 \\
55 \cdot 57 \\
50 \cdot 85 \\
46 \cdot 33 \\
41 \cdot 70 \\
37 \cdot 05 \\
32 \cdot 43 \\
27 \cdot 87 \\
23 \cdot 61 \\
19 \cdot 66 \\
16 \cdot 02 \\
12 \cdot 71 \\
9 \cdot 87 \\
7 \cdot 45 \\
5 \cdot 53\end{array}$ & $\begin{array}{r}65 \cdot 16 \\
66 \cdot 48 \\
62 \cdot 91 \\
58 \cdot 14 \\
53 \cdot 36 \\
48 \cdot 72 \\
44 \cdot 17 \\
39 \cdot 58 \\
35 \cdot 02 \\
30 \cdot 57 \\
26 \cdot 32 \\
22 \cdot 32 \\
18 \cdot 67 \\
15 \cdot 30 \\
12 \cdot 31 \\
9 \cdot 71 \\
7 \cdot 44 \\
5 \cdot 45\end{array}$ \\
\hline $\begin{array}{r}\text { Females } \\
0 \\
1 \\
5 \\
10 \\
15 \\
20 \\
25 \\
30 \\
35 \\
40 \\
45 \\
50 \\
55 \\
60 \\
65 \\
70 \\
75 \\
80\end{array}$ & $\begin{array}{r}70 \cdot 05 \\
71 \cdot 51 \\
67.99 \\
63 \cdot 23 \\
58 \cdot 41 \\
53 \cdot 74 \\
49 \cdot 19 \\
44 \cdot 62 \\
40 \cdot 04 \\
35 \cdot 47 \\
30 \cdot 98 \\
26 \cdot 63 \\
22 \cdot 46 \\
18 \cdot 48 \\
14 \cdot 81 \\
11 \cdot 48 \\
8 \cdot 70 \\
6.52\end{array}$ & $\begin{array}{r}70 \cdot 92 \\
71 \cdot 74 \\
68 \cdot 20 \\
63 \cdot 38 \\
58 \cdot 53 \\
53 \cdot 73 \\
49 \cdot 01 \\
44 \cdot 36 \\
39 \cdot 74 \\
35 \cdot 19 \\
30 \cdot 72 \\
26 \cdot 38 \\
22 \cdot 29 \\
18 \cdot 33 \\
14 \cdot 66 \\
11 \cdot 35 \\
8 \cdot 48 \\
6 \cdot 13\end{array}$ & $\begin{array}{r}71 \cdot 62 \\
72 \cdot 28 \\
68 \cdot 75 \\
63 \cdot 86 \\
58 \cdot 98 \\
54 \cdot 22 \\
49 \cdot 53 \\
44 \cdot 90 \\
40 \cdot 23 \\
35 \cdot 62 \\
31 \cdot 02 \\
26 \cdot 70 \\
22 \cdot 52 \\
18 \cdot 58 \\
14 \cdot 85 \\
11 \cdot 47 \\
8 \cdot 55 \\
6 \cdot 20\end{array}$ & $\begin{array}{r}70 \cdot 54 \\
71 \cdot 46 \\
67 \cdot 83 \\
63 \cdot 01 \\
58 \cdot 16 \\
53 \cdot 37 \\
48 \cdot 63 \\
43 \cdot 92 \\
39 \cdot 26 \\
34 \cdot 68 \\
30 \cdot 21 \\
25 \cdot 90 \\
21 \cdot 77 \\
17 \cdot 85 \\
14 \cdot 23 \\
11 \cdot 04 \\
8 \cdot 26 \\
5 \cdot 83\end{array}$ \\
\hline
\end{tabular}

U.S.A. but less at all higher ages. This indicates lower mortality in England and Wales compared with the U.S.A. (Wh) for older age groups, but a higher mortality for younger age groups. For life as a whole mortality is slightly less in England and Wales. Over all, however, it is obvious that mortality experience is very similar in these two countries, the summarizing index $\ddot{e}_{0}$ being $65 \cdot 16$ for the U.S.A. (Wh) and $65 \cdot 32$ for England and Wales. In the female tables, England and Wales appear to advantage in several parts, but the total mortality is less favourable than in any of the other countries. Approximately the same relationship as that seen for males also holds for females between England and Wales and the U.S.A. (Wh), but here the change comes later, at about 65 years of age. 


\section{English Life-Table Statistics throughout the 20Th Century}

The foregoing comparison prompts the question: how far does the character of mortality experience in England and Wales during the last two decades signalize a new trend ? Fig. 2 shows the summarizing index $\stackrel{\circ}{e}_{0}$ for both sexes, but for a closer scrutiny we may usefully supplement the conventional contents of the Life Table by recourse to a statistic based on $l_{x}$ and $T_{x}$ as defined above. This is the

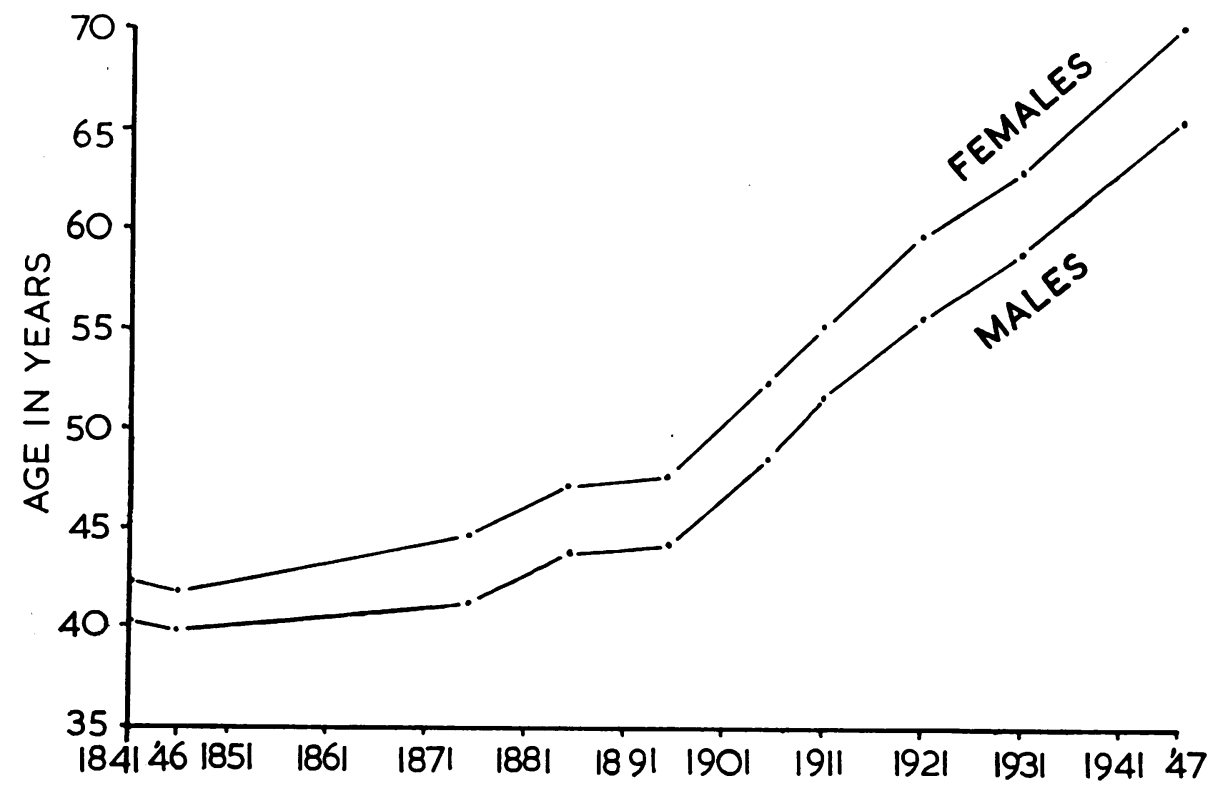

FIG. 2.- ¿̊̊ for England and Wales 1841-1947.

Source 1841-1931 English Census Life Tables. 1947 Abridged Life Tables.

ratio $Z_{x}=L_{\Delta} \div l_{x}$, being therefore the mean years of survival within the age group $x$ to $x+\Delta$. As such, it must lie between the limits 0 and $\Delta$. Consequently we can assign for each age group a measure of mortality with a definable maximum. Having done so, we are better able to see clearly in what age groups conservation of life has been most effective vis-à-vis the total expectation, and can henceforth accomplish little improvement.

The statistic $Z_{x}$, like $P_{x}$, summarizes the mortality experience of a particular age group at a point in time but from a different viewpoint. The latter tells us what proportion of persons survive throughout the interval. The former expresses the saturation level in terms of what proportion of the realizable span is still a target for conservation. $P_{x}$ is therefore restricted to periods where the mortality rate is constant, i.e. short periods where the rate might justifiably be represented by a straight line. $Z_{x}$ is not so restricted and may be used for comparing age periods of any size, provided those periods have the same realizable maximum $\Delta$. For 
TABLE IV

\begin{tabular}{|c|c|c|c|c|c|c|c|c|c|c|c|}
\hline Year & 1841 & $1838-54$ & $1871-80$ & $1881-90$ & $\begin{array}{c}1891- \\
1900\end{array}$ & 1901-10 & 1910-12 & $1920-22$ & $1930-32$ & -48 & Maxi- \\
\hline $\begin{array}{c}\text { Table } \\
\text { No. }\end{array}$ & (1) & (3) & (4) & (5) & (6) & (7) & (8) & (9) & & & \\
\hline$\underset{0-1}{\text { Males }}$ & 0.91 & $0 \cdot 89$ & 0.92 & 0.90 & 0.89 & 0.89 & 0.91 & 0.95 & 0.95 & 0.96 & 1 \\
\hline $\begin{array}{c}1-4 \\
5-9 \\
10-19 \\
20-29 \\
30-39 \\
40-59 \\
60-79 \\
80 \\
\text { and } \\
\text { over }\end{array}$ & $\begin{array}{r}3 \cdot 67 \\
4 \cdot 85 \\
9 \cdot 71 \\
9 \cdot 58 \\
9 \cdot 46 \\
17 \cdot 15 \\
12 \cdot 46 \\
\\
4 \cdot 94\end{array}$ & \begin{tabular}{|r|}
$3 \cdot 64$ \\
$4 \cdot 86$ \\
$9 \cdot 74$ \\
$9 \cdot 58$ \\
$9 \cdot 48$ \\
16.99 \\
12.42
\end{tabular} & \begin{tabular}{|r|}
$3 \cdot 67$ \\
$4 \cdot 90$ \\
$9 \cdot 81$ \\
$9 \cdot 66$ \\
$9 \cdot 49$ \\
$16 \cdot 78$ \\
$12 \cdot 12$
\end{tabular} & $\begin{array}{r}3 \cdot 72 \\
4 \cdot 93 \\
9 \cdot 88 \\
9 \cdot 72 \\
9 \cdot 54 \\
16 \cdot 94 \\
11 \cdot 97\end{array}$ & $\begin{array}{r}3 \cdot 74 \\
4 \cdot 93 \\
9 \cdot 87 \\
9 \cdot 74 \\
9 \cdot 61 \\
17 \cdot 04 \\
12 \cdot 00\end{array}$ & $\begin{array}{r}3 \cdot 80 \\
4 \cdot 95 \\
9 \cdot 89 \\
9 \cdot 79 \\
9 \cdot 68 \\
17 \cdot 48 \\
12 \cdot 41\end{array}$ & $\begin{array}{r}3 \cdot 83 \\
4 \cdot 95 \\
9 \cdot 90 \\
9 \cdot 81 \\
9 \cdot 72 \\
17 \cdot 73 \\
12 \cdot 63\end{array}$ & \begin{tabular}{|r|}
$3 \cdot 88$ \\
$4 \cdot 96$ \\
$9 \cdot 90$ \\
$9 \cdot 81$ \\
$9 \cdot 75$ \\
$18 \cdot 12$ \\
$13 \cdot 10$
\end{tabular} & $\begin{array}{r}3 \cdot 92 \\
4 \cdot 97 \\
9 \cdot 91 \\
9 \cdot 84 \\
9 \cdot 81 \\
18 \cdot 26 \\
13 \cdot 23 \\
\\
4 \cdot 80\end{array}$ & $\begin{array}{r}3.98 \\
4.99 \\
9.95 \\
9.91 \\
9.89 \\
18.69 \\
13.77 \\
\\
\\
5.54\end{array}$ & $\begin{array}{r}4 \\
5 \\
10 \\
10 \\
10 \\
20 \\
20\end{array}$ \\
\hline $\begin{array}{c}\text { Female } \\
0-1\end{array}$ & 0.94 & 0.91 & 0.93 & 0.92 & 0.91 & 0.92 & 0.93 & 0.96 & 0.96 & 0.97 & 1 \\
\hline $\begin{array}{c}1-4 \\
5-9 \\
10-19 \\
20-29 \\
30-39 \\
40-59 \\
60-79 \\
80 \\
\text { and } \\
\text { over }\end{array}$ & $\begin{array}{r}3 \cdot 67 \\
4 \cdot 86 \\
9 \cdot 70 \\
9 \cdot 57 \\
9 \cdot 47 \\
17 \cdot 37 \\
13 \cdot 02\end{array}$ & $\begin{array}{r}3 \cdot 65 \\
4 \cdot 87 \\
9 \cdot 72 \\
9 \cdot 56 \\
9 \cdot 46 \\
17 \cdot 25 \\
12 \cdot 96\end{array}$ & \begin{tabular}{|r|}
3.68 \\
4.90 \\
$9 \cdot 82$ \\
$9 \cdot 66$ \\
$9 \cdot 55$ \\
17.36 \\
12.90
\end{tabular} & $\begin{array}{r}3 \cdot 73 \\
4 \cdot 93 \\
9 \cdot 89 \\
9 \cdot 72 \\
9 \cdot 58 \\
17 \cdot 49 \\
12 \cdot 85\end{array}$ & $\begin{array}{r}3 \cdot 76 \\
4.93 \\
9 \cdot 86 \\
9 \cdot 77 \\
9 \cdot 65 \\
17.60 \\
12 \cdot 84\end{array}$ & $\begin{array}{r}3 \cdot 81 \\
4 \cdot 95 \\
9 \cdot 89 \\
9 \cdot 82 \\
9 \cdot 72 \\
17 \cdot 97 \\
13 \cdot 47\end{array}$ & $\begin{array}{r}3 \cdot 84 \\
4 \cdot 95 \\
9 \cdot 90 \\
9 \cdot 84 \\
9 \cdot 77 \\
18 \cdot 19 \\
13 \cdot 79\end{array}$ & \begin{tabular}{|r|}
$3 \cdot 89$ \\
$4 \cdot 96$ \\
$9 \cdot 89$ \\
$9 \cdot 84$ \\
$9 \cdot 80$ \\
$18 \cdot 54$ \\
$14 \cdot 32$ \\
\end{tabular} & $\begin{array}{r}3 \cdot 93 \\
4 \cdot 97 \\
9 \cdot 92 \\
9 \cdot 86 \\
9 \cdot 83 \\
18 \cdot 70 \\
14 \cdot 58\end{array}$ & $\begin{array}{r}3.98 \\
4.99 \\
9.96 \\
9.91 \\
9 \cdot 90 \\
19 \cdot 11 \\
15 \cdot 56\end{array}$ & $\begin{array}{r}4 \\
5 \\
10 \\
10 \\
10 \\
20 \\
20\end{array}$ \\
\hline
\end{tabular}

one age group (80 and over) we cannot assign an exact maximum, since $\Delta$ is indefinite. For purposes of comparison, however, we may arbitrarily define our $\Delta$ as 20 years, on the assumption that the proportion of centenarians among survivors to the age of 80 may remain trivial for many years ahead.

Table IV exhibits the actual $Z_{x}$ statistic calculated from the English Life Tables of 1841 onwards, and Table V (opposite) presents essentially the same picture in a more easily assimilable form, the figures being weighted to the same maximum (100). This statistic we denote by the symbol $R_{x}$. It will suffice to state the outcome in general terms, without emphasizing qualifications which the reader may judge appropriate by inspection of the figures cited in Tables IV and V, and of the graphs in Figs 3 and 4 (overleaf).

Phase 1.-For males from 1840 to 1900 , with due regard for errors in death registration during this period, a steady improvement is noticeable in all age groups from 1 to 39 , but none in the first year of life or in the age groups 40 and over.

Phase 2.-For males in the decade 1900-10 the steady improvement already noted 
TABLE V

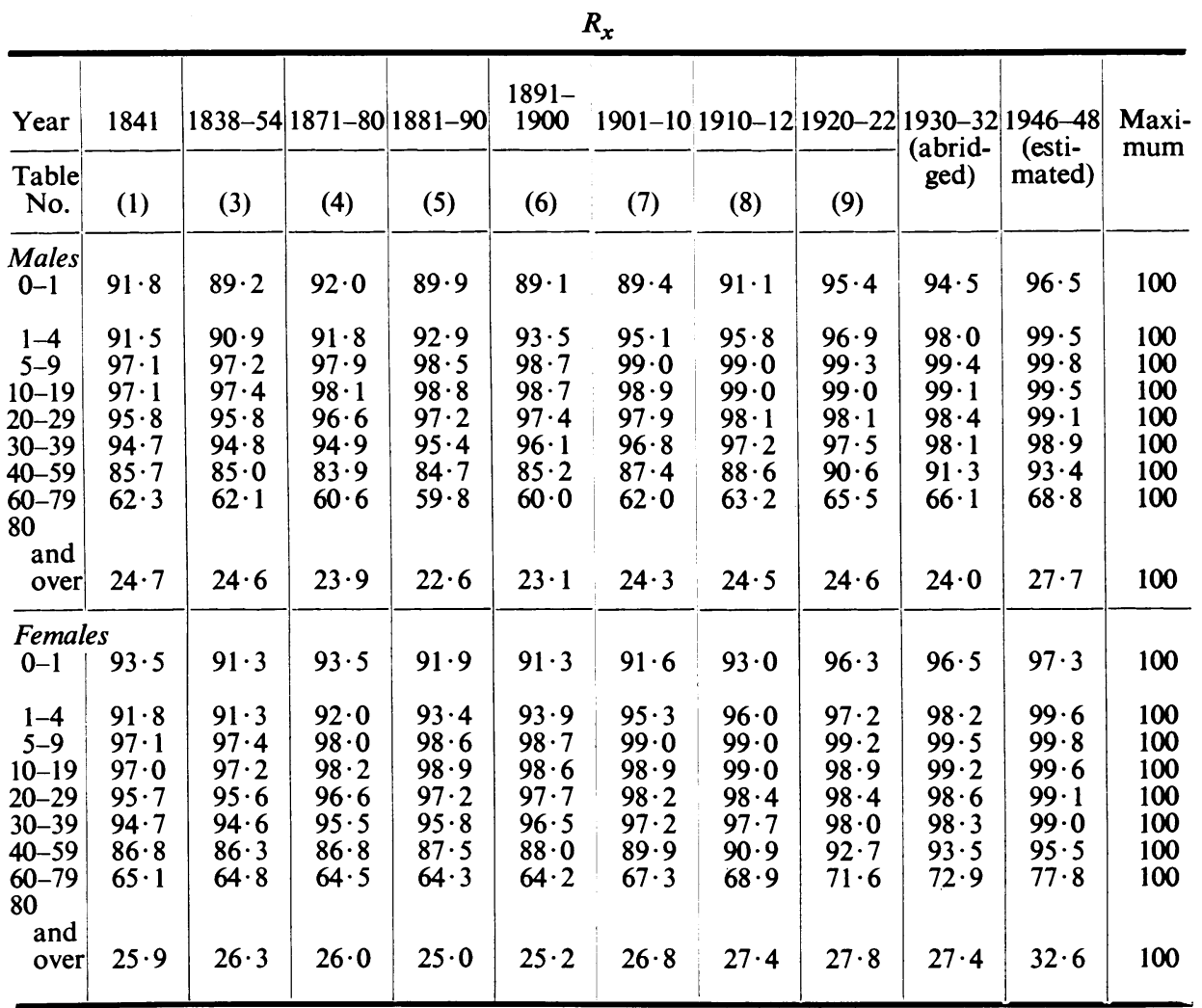

in the age group 1 to 39 inclusive continues, being most noticeable in the age group 1 to 4 , but we now see the beginning of a steady increase in the conservation of life in the first year and in the two decades 40 to 59 .

Phase 3.-For males between 1911 and 1931 the increased conservation of life in the first year increases to a more spectacular degree, though not consistently. Increased conservation of life in the age group 1 to 59 continues, and we first note a consistent improvement in the next 20 years, viz. 60 to 79 . For the terminal age group ( 80 and over) the 1931 figure is lower than at any time in the 20th century.*

\footnotetext{
* During this period there is an apparent fall from 1921 to 1931 in the figure for the conservation of life for males under one year of age. The method of calculation now used by the Government Actuary groups deaths in the first year of life by quarterly intervals. The more refined technique now generally adopted and here used for 1931 and 1947 is to group deaths 0-1 month, 1-3 months, 3-6 months, and 6-12 months. It is clear from the original data that neither policy has been followed consistently in the past, and that the statistics for the first year of life must be suspect until 1931. The effect of coarser grouping is to over-estimate the apparent conservation of life, since infant mortality is always greater in the immediate postnatal period. Thus the Official Life Table for 1931 would give $R_{x}=96.3$ male and 97.2 female in place of the 94.5 and 96.5 in Table V. It is a merit of the $R_{x}$ statistic that these deviations do not invalidate values at other ages in the Life Table. Since the recent past is of greater interest, it has been thought preferable to provide the correct figures for these dates although they are not strictly comparable with the earlier values for the first year of life.
} 


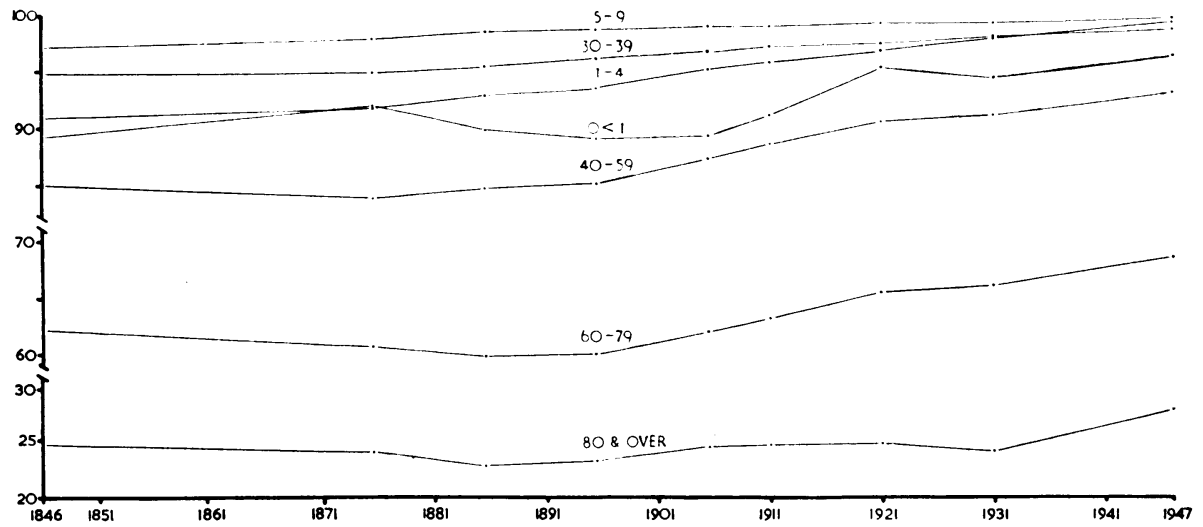

FIG. 3.- $R_{x}$ statistic for males, England and Wales, 1846-1947.

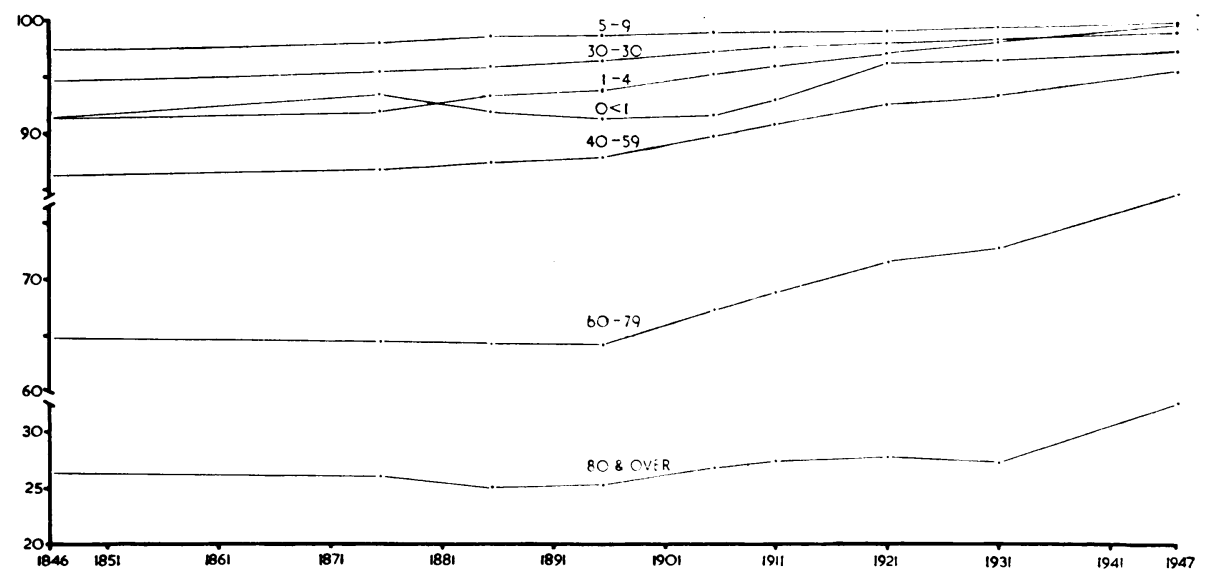

Fig. 4. $-R_{x}$ statistic for females, England and Wales, 1846-1947.

Phase 4.-For males the 1947 table, here set forth for the first time, would appear to signalize a new phase, the outstanding characteristic of which is a uniform increased conservation in all age groups, and its most diagnostic feature a spectacular rise in the oldest age group of all.

Broadly speaking, the foregoing remarks apply also to females, with two outstanding exceptions:

(a) the expectation of survival in the terminal age group, although less in 1931 than in 1921 or 1911 , is greater than for the 1900-10 period,

(b) the steady improvement which began after 1910 with respect to males of the age group 60 to 79 was already manifest in the previous decade (1901-10).

It should be noted at this point that whilst it is legitimate to compare historical series of $R_{x}$ with any size of age group, it is only legitimate to use age groups of 
equal size at a given point of time. This is because, by the nature of its construction, the survivors are taken at the mean age of the group, so that each additional year brings a successively smaller increase of $L_{\Delta}$. Table VI, therefore, gives the values of $Z_{x}$ for the 20th century in five vicennial groups, and Table VII gives the $R_{x}$ values.

TABLE VI

$Z_{x}$ FROM $1901-10$ TO $1946-48$

\begin{tabular}{|c|c|c|c|c|c|c|c|}
\hline Year & .. & .. & $1901-10$ & $1910-12$ & $1920-22$ & $\begin{array}{c}1930-32 \\
\text { (abridged) }\end{array}$ & $\begin{array}{c}1946-48 \\
\text { (estimated) }\end{array}$ \\
\hline \multirow{2}{*}{$\begin{array}{c}\text { Sex and Age } \\
\text { Group } . .\end{array}$} & Male & $\begin{array}{c}0-19 \\
20-39 \\
40-59 \\
60-79 \\
80 \text { and over } \\
\end{array}$ & $\begin{array}{r}15 \cdot 80 \\
19 \cdot 04 \\
17 \cdot 48 \\
12 \cdot 41 \\
4 \cdot 86 \\
\end{array}$ & $\begin{array}{r}16 \cdot 41 \\
19 \cdot 15 \\
17 \cdot 73 \\
12 \cdot 63 \\
4 \cdot 90 \\
\end{array}$ & $\begin{array}{r}17 \cdot 28 \\
19 \cdot 19 \\
18 \cdot 12 \\
13 \cdot 10 \\
4 \cdot 93 \\
\end{array}$ & $\begin{array}{r}17 \cdot 88 \\
19 \cdot 33 \\
18 \cdot 26 \\
13 \cdot 23 \\
4 \cdot 80 \\
\end{array}$ & $\begin{array}{r}18 \cdot 89 \\
19 \cdot 62 \\
18 \cdot 69 \\
13 \cdot 77 \\
5 \cdot 54\end{array}$ \\
\hline & Female & $\begin{array}{c}0-19 \\
20-39 \\
40-59 \\
60-79 \\
80 \text { and over }\end{array}$ & $\begin{array}{r}16 \cdot 33 \\
19 \cdot 18 \\
17 \cdot 97 \\
13 \cdot 47 \\
5 \cdot 36\end{array}$ & $\begin{array}{r}16 \cdot 88 \\
19 \cdot 28 \\
18 \cdot 19 \\
13 \cdot 79 \\
5 \cdot 49\end{array}$ & $\begin{array}{r}17 \cdot 70 \\
19 \cdot 30 \\
18 \cdot 54 \\
14 \cdot 32 \\
5 \cdot 56\end{array}$ & $\begin{array}{r}18 \cdot 28 \\
19 \cdot 40 \\
18 \cdot 69 \\
14 \cdot 58 \\
5 \cdot 48\end{array}$ & $\begin{array}{r}19 \cdot 13 \\
19 \cdot 63 \\
19 \cdot 11 \\
15 \cdot 56 \\
6 \cdot 52\end{array}$ \\
\hline
\end{tabular}

TABLE VII

$R_{x}$ FROM $1901-10$ TO $1946-48$

\begin{tabular}{|c|c|c|c|c|c|c|c|}
\hline Year & .. & .. & $1901-10$ & $1910-12$ & $1920-22$ & $\begin{array}{c}1930-32 \\
\text { (abridged) }\end{array}$ & $\begin{array}{c}1946-48 \\
\text { (estimated) }\end{array}$ \\
\hline \multirow{2}{*}{$\begin{array}{c}\text { Sex and Age } \\
\text { Group }\end{array}$} & Male & $\begin{array}{c}0-19 \\
20-39 \\
40-59 \\
60-79 \\
80 \text { and over }\end{array}$ & $\begin{array}{l}79 \\
95 \\
87 \\
62 \\
24\end{array}$ & $\begin{array}{l}82 \\
96 \\
89 \\
63 \\
24\end{array}$ & $\begin{array}{l}86 \\
96 \\
91 \\
65 \\
25\end{array}$ & $\begin{array}{l}89 \\
97 \\
91 \\
66 \\
24\end{array}$ & $\begin{array}{l}94 \\
98 \\
93 \\
69 \\
28\end{array}$ \\
\hline & Female & $\begin{array}{c}0-19 \\
20-39 \\
40-59 \\
60-79 \\
80 \text { and over }\end{array}$ & $\begin{array}{l}82 \\
96 \\
90 \\
67 \\
27\end{array}$ & $\begin{array}{l}84 \\
96 \\
91 \\
69 \\
27\end{array}$ & $\begin{array}{l}88 \\
96 \\
93 \\
72 \\
28\end{array}$ & $\begin{array}{l}91 \\
97 \\
93 \\
73 \\
27\end{array}$ & $\begin{array}{l}96 \\
98 \\
96 \\
78 \\
33\end{array}$ \\
\hline
\end{tabular}

ConClusions

The new life-table statistic $Z_{x}$ and its derivative ratio $R_{x}$ introduced in the foregoing treatment brings sharply into focus a conclusion which one might otherwise infer from mortality trends but with scarcely so much confidence.

The $1947 R_{x}$ values force upon our attention the conclusion that we are rapidly reaching saturation point with regard to the conservation of life in every age group under 60 years. Henceforth, therefore, any continued increase of expectation of life at birth can come about, in the main, only from a lowering of the risk of death in the older age groups.

That the increased expectation of life is due to the survival by more persons to a maximum span of life and not to an extension of the span by a few, is clearly shown by a comparison of $l_{x}$, the survivors of the Life Table. Half the males who start 
the course have died by age 67.2 in the $1930-32$ Table, but half survive to $70 \cdot 8$ in the 1946-48 Table. For females in the same period a similar effect is apparent, and here the change is from $71 \cdot 3$ to $75 \cdot 8$.

If we ask ourselves how big an increase in the conservation of life in the terminal age groups is conceivable, it is not likely that the limiting value for males will be below the present level for females. If so, a comparison of the $R_{x}$ values for males and females in 1947 is revealing. The present figure for males in the 40 to 59 age group (Table V) tallies closely with the figure for females in 1931. Now, from 1911 to 1947 , the rise in the figure for females in the age groups 40 to 59,60 to 79 , and 80 and over, has been $4 \cdot 6,8 \cdot 9$, and $5 \cdot 2$ per cent. respectively. The total expectation of life has risen during this period from 55.35 to 70.05 years. Meanwhile, the proportion of females surviving to age 40 has increased from 75 to $91 \cdot 1$ per cent., and to age 60 from 58.7 to 80.7 per cent. From the latest figures (i.e. 194648) the $R_{x}$ values for females exceed those for males in the three terminal age groups by $2 \cdot 1,9 \cdot 0$, and $4 \cdot 9$ per cent. respectively.

This brings us to an issue hotly contested by writers of the eugenics school, in particular Karl Pearson and Raymond Pearl. The former long maintained that conservation of life in the early years must on the whole promote the survival of individuals destined to succumb more readily than others at a more advanced age. $\mathrm{He}$ therefore argued that there must eventually be a fall in the expectation of life in the terminal age groups and sought confirmation for this view (Pearson, 1902, 1912; McDonnell, 1913) in an ingenious manipulation of highly dubious data concerning the age at death of Egypt an mummies and Roman remains.

In this study we have seen evidence of a sustained increase in the expectation of life at ages over 60 for a period of nearly half a century, and the new figures presented indicate the possibility of a substantial improvement in the age group 80 and over. In view of the highly controversial nature of this issue, therefore, it is important to scrutinize the last conclusion with due regard to certain adjustments of the relevant data rendered necessary because the populations are not divisible after age 84 in the crude data supplied by the Registrar-General. Our task would thus be incomplete if we did not supplement the foregoing tables with a scrutiny of the two terminal quinquennials for which our figures are complete. Accordingly, Table VIII shows the value of $R_{x}$ for these groups.

TABLE VIII

$R_{x}$ FROM 1841 TO $1946-48$

\begin{tabular}{c|c|c|c|c|c|c|c|c|c|c}
\hline Year & 1841 & $1838-54$ & $1871-80$ & $1881-90$ & $1891-$ & $1901-10$ & $1910-12$ & $1920-22$ & $1930-32$ & $1946-48$ \\
\hline $\begin{array}{c}\text { Males } \\
75-79 \\
80-84\end{array}$ & 77 & 76 & 76 & 75 & 75 & 76 & 76 & 77 & 77 & 80 \\
\hline $\begin{array}{c}\text { Females } \\
75-79\end{array}$ & 78 & 78 & 67 & 66 & 66 & 68 & 68 & 68 & 69 & 72 \\
$80-84$ & 70 & 70 & 70 & 77 & 77 & 79 & 80 & 81 & 81 & 84 \\
\hline
\end{tabular}


It might justly be said that the outcome of this examination emphasizes the temerity of making forecasts of human affairs on the basis of the theory of natural selection, without due regard to man's ability to generate his own environment. The work of Enid Charles and others has accustomed us to anticipate an ageing population as a consequence of greatly diminished fertility accompanying a fall of mortality in the age groups under 60 ; but known facts hitherto have not forced intelligent anticipation of this sort, albeit arresting, to envisage the outcome of any spectacular fall of mortality in the older age-groups. That we may indeed expect a substantial conservation of life, at least up to the limit at which human beings retain any power to contribute to the working life of the community, is a prospect with far-reaching social consequences. We may now expect that advancing medical science and improved social conditions will conspire to increase the tempo of the ageing of the population, a prospect already recognized by demographers as the inescapable outcome of lower fertility. Whereas fertility must not fall below its present level if the population is to maintain itself, we can foresee no early arrest to a process which will inevitably increase the proportion of old age pensioners in the population.

Acknowledgements are due to Dr. Enid Charles, and to Professor L. Hogben, F.R.S., for advice and criticism.

\section{REFERENCES}

Dublin, L. I., Lotka, A. J., and Spiegelman, M. (1949). “ Length of Life ”, 2nd ed. Ronald Press, New York.

Duvillard, E. E. (1806). “Analyse et Tableaux de l'Influence de la Petite Vérole sur la Mortalité à chaque Age”. Imprimérie Impériale, Paris.

Farr, W. (1843). In "Fifth Annual Report of the Registrar-General (for 1842)."

(1875). In " Supplement to the 35th Annual Report of the Registrar-General (for 1861-1870) ". Preliminary Tables.

Halley, E. (1693). Philos. Trans., 17, 596-610 and 654-56.

Kuczynski, R. R. (1935). “The Measurement of Population Growth.” Sidgwick and Jackson, London. Macdonell, W. R. (1913). Biometrika, 9, 366.

Milne, J. (1815). In "Encyclopaedia Britannica”, Suppl. to 4th, 5th and 6th ed., vol. 5, pp. 546ff (1824). Article, “ Mortality, Human, Law of".

Pearson, K. (1902). Biometrika, 1, 263.

(1912). Proc. roy. Soc. B., 85, 469.

Price, R. (1783). " Observations on Reversionary Payments ”, 4th ed., p. 358. London.

Registrar-General (1936). “Decennial Supplement, England and Wales, 1931", Part 1, Life Tables. (1947, 1948, 1950). "Statistical Review of England and Wales for 1946, 1947, and 1948 ", Tables, Part 1, Medical. H.M.S.O., London.

(1949). "Estimates of the Sex and Age Distribution of the Civilian Population . . . of England and Wales, as at December 31, 1947." H.M.S.O., London.

United Nations (1948) Demographic Yearbook. U.N.O., Lake Success, N.Y.

\section{TECHNICAL APPENDIX \\ CONSTRUCTION OF THE 1946-1948 LIFE TABLE}

It is advisable to calculate Life Tables from census material if available, since accurate sources are important. The tables for 1946-1948 are based, however, on the Registrar-General's Estimate of Civilian Population at December 31, 1947, and Civilian Deaths in the years 1946, 1947, and 1948. Needless to say, there is no absolute reason why a 3-year average of deaths should be used. It was adopted first for the 1911 Census Life Tables (English Life Table No. 8), Life Table No. 7 
being based upon the censuses of 1901 and 1911, and the deaths from 1901 to 1910. The 3-year average has the advantage of giving a closer approximation to current mortality without the disadvantage of allowing the choice of one particular abnormal year to give a false view of contemporary mortality.*

It was decided to use the Kuczynski method for this purpose because the implications of the Reed-Merrell and Greville methods are less apparent. Since by the nature of the data the 1946-48 tables are abridged, a similar table was computed for the 1930-32 period for comparison. The differences between this table and the complete table of the Registrar-General for 1930-32 were found to be trivial, except for the first year of life.

In computing Life Tables for this period, three points are noteworthy:

(1) Since deaths by age are only obtainable for the calendar year as a whole, it is clear that the estimates are not at exactly the mid-point of the period of deaths. It has been assumed, therefore, that estimates of population as at June 30, 1947 , would have given the same age groups as those actually found 6 months later. Since $P_{0}$ to $P_{5}$ were computed after an examination of births, this assumption does not introduce any serious error.

(2) In this period, H.M. forces consist of their pre-war regular embodiment (comparable to 1931), a number of re-engaged conscripts, and the 18 to 20-year-old National Servicemen. The use of civilian death and population statistics tends to overweight the mortality of males in the 15 to 19 and 20 to 24 age groups, but the effect is small. The cumulative effect is slightly to decrease the $\dot{e}_{x}$ at these and earlier ages.

(3) Some approximation has to be made to the tail of the life table, since the Registrar-General's estimates have the terminal group " 85 and over". This tail adds 0.7 per cent. and 1.4 per cent. to the $T_{x}$ for males and females respectively, and it is clear that no appreciable error is introduced in this necessary adjustment. In general, however, the values for all ages over 84 should be regarded as approximations.

There is a dearth of other calculations based on Life Tables over this period. The Royal Commission on Population (1950) published a Hypothetical Life Table for 1942-44, but, as the memorandum states:

" the table is essentially hypothetical in character".

Lessof (1949) gives $\dot{e}_{0}$ for England and Wales in 1936-38, but it is impossible to agree with these figures which show a lower value for females than those of the Registrar-General for 1931 and 1938.

ReFerences in APPENDiX

Lessof, E. (1949). Population Studies, 3, 76.

Logan, W. P. D. (1950). Ibid., 4, 134.

Royal Commission on Population (1950). Papers of the R. Com. Pop., Vol. 2, " Reports and Selected Papers of the Statistics Committee." H.M.S.O., London.

* The danger of basing conclusions on a single year's mortality is exemplified by Logan (1950). Here a decrease in mortality rates for age group 85 and over for males is shown to be 2 per cent. from 1921/25 until 1947. Had the writer used 1946 figures, the decrease would have been 12 per cent., and with 1948 statistics it would have been 19 per cent. 